\title{
PENGEMBANGAN KEMAMPUAN FISIK MOTORIK MELALUI PERMAINAN TRADISIONAL BAGI ANAK USIA DINI
}

\author{
Oleh: \\ Uswatun Hasanah, M.Pd.I. \\ STAIN Jurai Siwo Metro Lampung \\ u.hasanah19@rocketmail.com
}

\begin{abstract}
Abstrak
Anak-anak sangat dekat dengan permainan. Dalam kehidupan sehari-hari, permainan baik tradisional maupun modern selalu dilakukan anak-anak. Permainan yang dilakukan merupakan sesuatu yang dianggap wajib dilakukan sebagai sarana untuk perkembangan fisik motorik bagi Anak Usia Dini. Permainan modern yang sekarang ini sering dimainkan oleh anak-anak di perkotaan lebih cenderung mengasah kemampuan otak daripada kemampuan otot, oleh karena itu kepada para orang tua yang tinggal di perkotaan disarankan lebih memperkenalkan pada anak-anak mengenai jenis-jenis permainan yang lebih melatih kekuatan otot-otot mereka dan permainan tradisional dapat menjadi salah satu solusinya. Permainan tradisionalpun perlahan namun pasti mulai ditinggalkan, karena dianggap kuno serta melelahkan. Padahal jika ditinjau lebih dalam, beragam permainan tradisional secara langsung dapat memberikan kontribusi kepada anak-anak diantaranya berupa: 1) pembentukan fisik yang sehat, bugar, tangguh, unggul dan berdaya saing; 2)pembentukan mental meliputi: sportivitas, toleran, disiplin dan demokratis; 3)Pembentukan moral menjadi lebih tanggap, peka, jujur dan tulus; 4) pembentukan kemampuan sosial, yaitu mampu bersaing, bekerjasama, berdisiplin, bersahabat, dan berkebangsaan.
\end{abstract}

Kata Kunci: Fisik motorik, Permainan Tradisional.

\begin{abstract}
Children are very close to the game. In daily life, children always do both traditional and modern games. The game is something that is considered mandatory as a means of physical motor development for Early Childhood.The modern game is often played by children in urban areas tend to improve the ability of the brain than muscles. therefore, the parents who live in urban areas is more advisable to introduce the children to the kinds of games that are more trained strength of their muscles, and traditional games can be one of the solution.The traditional game was slowly but surely becoming obsolete, because it is considered archaic and exhausting. In fact, if evaluated deeper, a variety of traditional games can directly contribute to children such as:1) establishment of a healthy physical, fit, strong, superior and competitive;2) mental development, include: sportsmanship, tolerance, discipline and democratic;3) Theestablishment of moral become more responsive, sensitive, honest and sincere;4) establishment of social skills, are able to compete, cooperate, disciplined, friendly, and nationality.
\end{abstract}

Keywords: Physical motor, Traditional Games.

\section{PENDAHULUAN}

Pendidikan adalah proses pengubahan sikap dan tata laku seseorang atau kelompok orang untuk mendewasakan manusia melalui upaya pengajaran dan pelatihan. Sejak dini manusia sudah membutuhkan pendidikan dalam proses perkembangannya menjadi dewasa. Perkembangan anak pada tahuntahun pertama sangat penting dan akan menentukan kualitasnya di masa depan. Anak adalah individu yang berbeda, unik, dan memiliki karakteristik sendiri sesuai dengan tahapan usianya. Oleh karena itu, upaya-upaya pengembangan anak usia dini hendaknya dilakukan melalui belajar dan 
bermain. (Novan Ardy Wiyani dan Barnawi, 2012:72).

Satuan pendidikan anak usia dini (PAUD) merupakan salah satu bentuk penyelenggaraan pendidikan yang menitikberatkan pada peletakan dasar ke arah pertumbuhan dan perkembangan yaitu, nilai moral dan agama (spiritual), fisik (koordinasi motorik halus dan kasar), kognitif (daya fikir dan daya cipta), sosialemosional (sikap dan perilaku serta beragama), dan bahasa sesuai dengan keunikan dan tahap-tahap perkembangan yang dilalui oleh anak usia dini, "tujuan pembelajaran di PAUD atau taman kanakkanak adalah untuk membantu meletakkan dasar ke arah perkembangan sikap, pengetahuan, keterampilan, dan daya cipta yang diperlukan oleh anak didik dalam menyesuaikan diri dengan lingkungannya dan untuk pertumbuhan dan perkembangan selanjutnya" (Yeni Rachmawati, 2011:1).

Anak usia dini bertumbuh dan berkembang menyeluruh secara alami. Jika pertumbuhan dan perkembangan tersebut dirangsang maka akan mencapai. Aspek perkembangan motorik merupakan salah satu aspek perkembangan yang dapat mengintegrasikan perkembangan aspek yang lain. Menurut UU Nomor 20 Tahun 2003 Bab I Pasal 1 Ayat 14 tentang pendidikan bahwa: Pendidikan anak usia dini adalah suatu upaya pembinaan yang ditujukan kepada anak sejak lahir sampai dengan usia enam tahun yang dilakukan melalui pemberian rangsangan pendidikan untuk membantu pertumbuhan dan perkembangan jasmani dan rohani agar anak memiliki kesiapan dalam memasuki pendidikan lebih lanjut. Pendidikan anak usia dini (early childhood education/ PAUD) sangat penting dilaksanakan sebagai dasar bagi pembentukan kepribadian manusia secara utuh, yaitu pembentukan karakter, budi pekerti luhur, cerdas, ceria, terampil, dan bertakwa, kepada Tuhan yang Maha Esa. (Permendiknas Nomer 58, 2009:3). Peraturan Menteri Pendidikan Nasional
Republik Indonesia Nomor 58 tahun 2009 menyatakan bahwa "tujuan Pendidikan Taman Kanak-kanak adalah membantu anak didik mengembangkan berbagai potensi baik psikis dan fisik yang meliputi lingkup perkembangan nilai agama dan moral, fisik/motoric, kognitif, bahasa, serta sosial emosional kemandirian". (Permendiknas Nomer 58, 2009:4)

Usia dini merupakan kesempatan emas bagi anak untuk belajar, sehingga disebut usia emas (golden age). Pada usia ini, anak memiliki kemampuan untuk belajar yang luar biasa. (Mursid, 2015: 121).

PAUD juga merupakan masa emas dalam pertumbuhan dan perkembangan pada anak, maka dari itu pentingnya mengarahkan dan membimbing anak dengan membangun karakter positif pada anak dan menyeimbangkan seluruh aspek perkembangannya agar berkembang sesuai dengan tahap usianya, "PAUD sebagai pendidikan yang diselenggarakan sebelum jenjang pendidikan dasar, memiliki kelompok sasaran anak usia 0-6 tahun yang sering disebut sebagai masa emas perkembangan" (Latif, 2013:3).

Pemahaman tentang Anak merupakan suatu awal keberhasilan dalam pendidikan. Dunia anak merupakan dunia bermain, di saat mereka bermain anakanak akan menyerap segala sesuatu yang terjadi di lingkungan sekitarnya, "bermain juga merupakan tuntutan dan kebutuhan yang esensial bagi anak usia dini, melalui bermain anak akan dapat memuaskan tuntutan dan kebutuhan perkembangan dimensi dari motorik, kognitif, kreativitas, bahasa, emosi, sosial, nilai, dan sikap hidup" (Moeslichatoen, 2006:27).

Anak merupakan amanah Allah kepada kedua orangtuanya, hatinya masih suci bagaikan mutiara yang indah, bersih dan kosong dari segala ukiran gambar. Dia siap menerima segala ukiran dan cenderung kepada setiap apa yang diarahkan kepadanya. Anak yang mendapatkan pembinaan yang tepat pada usia dini akan dapat meningkatkan 
kesehatan serta kesejahteraan fisik dan mental, yang berdampak pada peningkatan prestasi belajar anak, etos kerja anak, dan produktivitas sehingga mampu mandiri dan mengoptimalkan potensi dirinya (Ihsana El-Khuluqo, 2015:40)

Setiap orangtua atau pendidik menginginkan buah hati atau anak didiknya tumbuh menjadi anak yang cerdas, sehat, mandiri, kreatif. Untuk mewujudkan hal tersebut, maka orangtua atau pendidik perlu mengenal dan memahami dengan baik tentang dunia anak dengan baik. Sebab dunia anak berbeda dengan orang dewasa. Dunia anak adalah bermain. Dan pada dasarnya peran orangtua atau pendidik adalah mengarahkan anak-anak tersebut sebagai generasi unggul. Adanya program pengembangan keterampilan motorik anak usia dini, seringkali dilupakan bahkan diabaikan oleh orangtua atau pendidik. Hal ini dikarenakan belum memahami bahwa program pengembangan keterampilan motorik yang tak terpisahkan dalam pendidikan anak usia dini. Berikut ini akan penulis sajikan mengenai pentingnya permainan tradisional dalam pengembangan fisik motorik bagi anak usia dini.

\section{Definisi Pertumbuhan dan Perkembangan}

Setiap organisme pasti mengalami peristiwa perkembangan selama hidupnya. Perkembangan ini meliputi seluruh bagian dengan keadaan yang dimiliki oleh organisme ini, baik yang bersifat konkret maupun yang bersifat abstrak. Jadi, peristiwa perkembangan itu, khususnya perkembangan manusia, tidak hanya tertuju pada aspek psikologis saja, tetapi juga aspek biologis.

Djaali dalam Helmawati (2015: 10) mengemukakan bahwa pertumbuhan diartikan perubahan kuantitatif pada material sesuatu sebagai akibat dari adanya pengaruh lingkungan. Sedangkan definisi perkembangan menurut F.J. Monk, dkk mendefinisikan bahwa perkembangan adalah suatu proses yang kekal dan tetap menuju ke arah suatu organisasi pada tingkat integrasi yang lebih tinggi berdasarkan proses pertumbuhan.

Selain itu, perkembangan diartikan sebagai suatu proses yang menuju kedepan dan tidak dapat diulang kembali. Dalam perkembangan manusia terjadi perubahanperubahan yang sedikit banyak bersifat tetap dan tidak dapat diulangi. (Abu Ahmadi \& Munawar Sholeh, 2005: 1)

$$
\text { Secara umum, definisi }
$$

perkembangan dan pertumbuhan memiliki pengertian yang sama yakni keduanya mengalami perubahan. Tetapi secara khusus, pertumbuhan adalah mengacu pada perubahan yang bersifat kuantitas, sedang perkembangan lebih mengarah kepada kualitas. Artinya konsep pertumbuhan mengandung definisi sebagai perubahan ukuran fisik yang bersifat pasti, akurat yakni dari kecil menjadi besar, dari sempit menjadi lebar. Selain itu, yang terpenting dalam pertumbuhan ialah terjadinya proses pematangan fisik yang ditandai dengan makin kompleksnya sistem jaringan otot, sistem syaraf maupun sistem fungsi organ tubuh. Kematangan tersebut, menyebabkan organ fisik merasa siap untuk dapat melakukan tugas-tugas dan aktivitas sesuai dengan tahap perkembangan individu. Jadi perkembangan dapat diartikan sebagai akibat dari perubahan kematangan dan kesiapan fisik yang memiliki potensi untuk melakukan suatu aktivitas, sehingga individu telah mempunyai suatu pengalaman. (Agoes Dariyo, 2007: 35)

\section{Aspek Perkembangan Anak Usia Dini}

Catron dan Allen dalam Yuliani Nurani Sujiono (2009: 62) mengemukakan bahwa terdapat 6 aspek perkembangan anak usia dini, yaitu:

1. Kesadaran personal

Permainan yang preatif
memungkinkan perkembangan
kesadaran personal. Bermain
mendukung anak untuk tumbuh secara
mandiri dan memiliki kontrol atas
lingkungannya. Melalui bermain, anak


dapat menemukan hal yang baru, bereksplorasi, meniru, dan mempraktikkan kehidupan sehari-hari sebagai sebuah langkah dalam membangun keterampilan menolong dirinya sendiri, keterampilan ini membuat anak merasa kompeten.

2. Pengembangan Emosi

Melalui bermain, anak dapat belajar menerima, berekspresi dan mengatasi masalah dengan cara yang positif. Bermain juga memberikan kesempatan pada anak untuk mengenal diri mereka sendiri dan untuk mengembangkan pola perilaku yang memuaskan dalam hidup.

3. Membangun sosialisasi

Bermain memberikan jalan bagi perkembangan sosial anak ketika berbagi dengan anak lain. Bermain adalah sarana yang paling utama bagi pengembangan kemampuan bersosialisasi dan memperluas empati terhadap orang lain serta mengurangi sikap egosentrisme. Bermain dapat menumbuhkan dan meningkatkan rasa sosialisasi anak. Melalui bermain anak dapat belajar perilaku prososial seperti: menunggu giliran, kerja sama, saling membantu dan berbagi.

4. Pengembangan Komunikasi

Bermain merupakan alat yang paling kuat untuk membelajarkan kemampuan berbahasa anak. Melalui komunikasi inilah anak dapat memperluas kosa kata dan mengembangkan daya penerimaan serta pengekpresian kemampuan berbahasa mereka melalui interaksi dengan anak-anak lain dan orang dewasa pada situasi bermain spontan.

5. Pengembangan kognitif

Bermain dapat memenuhi kebutuhan anak untuk secara aktif terlibat dengan lingkungan, untuk bermain dan bekerja dalam menghasilkan suatu karya, serta untuk memenuhi tugastugas perkembangan kognitif lainnya. Selama bermain, anak menerima pengalaman baru, memanipulasi bahan dan alat, berinteraksi dengan orang lain dan mulai merasakan dunia mereka. Bermain menyediakan kerangka kerja pada anak untuk mengembangkan pemahaman tentang diri mereka sendiri, orang lain dan lingkungan.

6. Pengembangan kemampuan motorik Bermain memberikan kesempatan yang luas untuk bergerak pada anak, pengalaman belajar untuk menemukan, , aktivitas sensori motor, yang meliputi penggunaan otot-otot besar dan kecil memungkinkan anak untuk memenuhi perkembangan perseptual motorik.

\section{Perkembangan Fisik Motorik Anak}

Menurut Agoes Dariyo (2007: 43) mengemukakan bahwa yang paling menonjol dan nampak dalam diri individu adalah terjadinya perubahan fisik. Hal ini terbukti dengan adanya perubahan fisik individu yang terjadi sangat cepat yakni sejak masa konsepsi hingga masa kelahirannya. Kemudian dilanjutkan masa bayi, anak-anak, remaja dan dewasa.

Fisik atau tubuh manusia merupakan sistem organ yang kompleks dan sangat mengagumkan. Semua organ ini terbentuk pada periode pranatal (dalam kandungan). Berkaitan dengan perkembangan fisik menurut Kuhlen dan Thompson dalam Syamsu Yusuf LN. (2014:101) mengemukakan bahwa perkembangan fisik individu meliputi empat aspek yaitu: (1) Sistem syaraf, yang sangat mempengaruhi perkembangan kecerdasan dan emosi; (2)Otot-otot, yang mempengaruhi perkembangan kekuatan dan kemampuan motorik; (3) Kelenjar Endokrin, yang menyebabkan munculnya pola-pola tingkah laku baru, seperti pada usia remaja berkembang perasaan senang untuk aktif dalam suatu kegiatan, yang sebagian anggotanya terdiri atas lawan jenis; dan (4) Struktur fisik/tubuh, yang meliputi tinggi, berat dan proporsi. 
Gerakan motorik atau adalah suatu istilah yang digunakan untuk menggambarkan perilaku gerakan yang dilakukan oleh tubuh manusia. Pengendalian motorik biasanya digunakan dalam bidang ilmu psikologi, fisiologi, neurofisiologi maupun olah raga. Proses tumbuh kembang kemampuan gerak seorang anak. Pada dasarnya, perkembangan Perkembangan motorik adalah ini berkembang sejalan dengn kematangan saraf dan otot anak. Sehingga, setiap gerakan sesederhana apapun, adalah merupakan hasil pola interaksi yang kompleks dari berbagai bagian dan system dalam tubuh yang dikontrol oleh otak.

Keterampilan Motorik adalah gerakan-gerakan tubuh atau bagian-bagian tubuh yang disengaja, otomatis, cepat dan akurat. Gerakan-gerakan ini merupakan rangkaian koordinasi dari beratus-ratus otot yang rumit. Ketrampilan motorik ini dapat dikelompokkan menurut ukuran otot-otot dan bagian-bagian badan yang terkait, yaitu keterampilan motorik kasar (gross motor skill) dan keterampilan motorik halus (fine motor skill). Secara garis besarnya, urutan perkembangan keterampilan motorik ini mengikuti dua prinsip. Pertama, prinsip chepalocaudal (dari kepala ke ekor), menunjukkan urutan perkembangan, dimana bagian atas badan lebih dahulu berfungsi dan terampil digunakan sebelum bagian yang lebih rendah. Bayi terlebih dahulu belajar memutar kepalanya sebelum belajar menggerakkan kaki dengan sengaja, dan mereka belajar menggerakkan kaki. Kedua, Prinsip proximodistal (dari dekat ke jauh), menunjukkan perkembangan keterampilan motorik, dimana bagian tengah badan lebih dahulu terampil sebelum dibagian-bagian sekelilingnya atau bagian yang lebih jauh. Bayi belajar melambaikan keseluruhan lengannya sebelum belajar menggoyangkan pergelangan tangan dan jari-jarinya. Penulis membagi keterampilan motorik menjadi dua bagian, yaitu: 1) keterampilan motorik kasar; 2) keterampilan motorik
halus.Keterampilan motorik kasar (gross motor skill), meliputi keterampilan otototot besar lengan, kaki, dan batang tubuh, seperti berjalan dan melompat. Sedangkan, Keterampilan motorik halus (fine motor skill), meliputi otot-otot kecil yang ada diseluruh tubuh, seperti menyentuh dan memegang. (Desmita, 2013: 97-99)

Berkaitan dengan kemampuan motorik menurut Waharsono dalam Edy Waspada (2014: 33) mengemukakan bahwa sejalan dengan meningkatnya ukuran tubuh dan meningkatnya kemampuan fisik, maka meningkat pulalah kemampuan geraknya. Adapun perkembangan kemampuan fisik pada anak kecil menurut mursid (2015: 126127) bisa diidentifikasikan dalam beberapa hal. Sifat-sifat perkembangan fisik yang dapat diamati adalah sebagai berikut:

1. Terjadi perkembangan otot-otot besar cukup cepat pada usia 2 tahun terakhir masa anak kecil. Hal ini memungkinkan anak melakukan berbagai gerakan yang lebih leluasa yang kemudian bisa dilakukannya bermacam-macam keterampilan gerak dasar. Beberapa macam gerak dasar meliputi: meloncat, berlari, melempar, menangkap, dan memukul berkembang secara bersamaan tetapi dengan irama perkembangan yang berlainan.

2. Dengan berkembangnya otot-otot besar, terjadi pulalah perkembangan kekuatan yang cukup cepat, baik pada anak laki-laki maupun perempuan.

3. Pertumbuhan kaki dan tangan secara proporsional lebih cepat dibanding pertumbuhan bagian tubuh yang lain, menghasilkan peningkatan daya ungkit yang lebih besar di dalam melakukan gerakan yang melibatkan tangan dan kaki.

4. Terjadi peningkatan koordinasi gerak dan keseimbangan tubuh yang cukup cepat.

5. Meningkatnya kemungkinan dan kesempatan melakukan berbagai macam aktivitas gerak fisik bisa 
merangsang perkembangan pengenalan konsep-konsep dasar objek, ruang, gaya, waktu dan sebab akibat.

Secara keseluruhan, perkembangan keterampilan motorik merupakan faktor yang sangat penting bagi perkembangan pribadi pada anak.

\section{Pencapaian perkembangan Motorik Kasar dan Halus Pada Anak Usia Dini}

Pencapaian suatu kemampuan pada setiap anak bisa berbeda-beda, namun demikian ada patokan umur tentang kemampuan apa saja yang perlu dicapai seorang anak pada usia tertentu. Adanya patokan tersebut adalah dimaksudkan supaya anak yang belum mencapai tahap kemampuan tertentu ini perlu di latih berbagai kemampuan untuk dapat mencapai perkembangan yang optimal. (Ahmad Susanto, 2011: 163)

Pada umumnya, pembelajaran di TK untuk aspek perkembangan fisik atau motoriknya lebih banyak difokuskan pada motorik halus. Sedangkan motorik kasar kurang diperhatikan. Padahal pengembangan motorik kasar pada anak usia dini juga perlu bimbingan dari pendidik. Perkembangan motorik kasar sama pentingnya dengan aspek perkembangan lainnya, karena ketidakmampuan anak melakukan kegiatan fisik maka akan menimbulkan konsep diri negatif pada diri anak. (Mursid, 2015: 122) Secara singkat mengenai pencapaian perkembangan motorik kasar dan motorik halus pada masa anak-anak awal ini dapat digambarkan dalam tabel dibawah ini:

Tabel 1.1. Perkembangan motorik kasar dan motorik halus usia $<3$ bulan -12 bulan

\begin{tabular}{|c|c|c|c|c|c|}
\hline \multirow[t]{2}{*}{ No } & \multirow{2}{*}{$\begin{array}{c}\text { Lingkup } \\
\text { Perkembangan }\end{array}$} & \multicolumn{4}{|c|}{ Tingkat Pencapaian Perkembangan } \\
\hline & & Usia $<3$ bulan & $3-<6$ bulan & $6-<9$ bulan & $9-<12$ bulan \\
\hline 1. & Motorik Kasar & $\begin{array}{l}\text { 1.Refleks } \\
\text { menggenggam } \\
\text { benda yang } \\
\text { menyentuh } \\
\text { telapak tangan. } \\
2 . \\
\text { Menegakkan } \\
\text { kepala saat } \\
\text { ditelungkupka } \\
\text { n. } \\
\text { Tengkurap. } 4 . \\
\text { Berguling ke } \\
\text { kanan dan ke } \\
\text { kiri. }\end{array}$ & $\begin{array}{l}\text { 1. Meraih } \\
\text { benda di } \\
\text { depannya. } 2 . \\
\text { Tengkurap } \\
\text { dengan dada } \\
\text { diangkat dan } \\
\text { kedua tangan } \\
\text { menopang. } 3 . \\
\text { Duduk dengan } \\
\text { bantuan. }\end{array}$ & \begin{tabular}{lr}
\multicolumn{3}{l}{ 1.Melempar } \\
benda yang \\
dipegang 2. \\
Merangkak & ke \\
segala arah. 3. & . \\
Duduk tanpa \\
bantuan. & 4. \\
Berdiri & \\
dengan & \\
bantuan. & 5. \\
Bertepuk & \\
tangan.
\end{tabular} & $\begin{array}{l}\text { 1.Menarik benda } \\
\text { yang terjangkau. } \\
\text { 2. Berjalan } \\
\text { dengan } \\
\text { berpegangan. } 3 \text {. } \\
\text { Berjalan beberapa } \\
\text { langkah tanpa } \\
\text { bantuan. } 4 \text {. } \\
\text { Melakukan gerak } \\
\text { menendang bola. }\end{array}$ \\
\hline 2 & Motorik Halus & $\begin{array}{l}\text { 1. Memainkan } \\
\text { jari tangan dan } \\
\text { kaki. } \\
\text { Memegang } \\
\text { benda dengan } \\
\text { lima jari. }\end{array}$ & $\begin{array}{l}1 . \\
\text { Memasukkan } \\
\text { benda ke dalam } \\
\text { mulut. } 2 . \\
\text { Memindahkan } \\
\text { mainan dari } \\
\text { satu tangan ke } \\
\text { tangan yang } \\
\text { lain }\end{array}$ & $\begin{array}{l}\text { Memegang } \\
\text { benda dengan } \\
\text { ibu jari dan } \\
\text { jari telunjuk } \\
\text { (menjumput) } \\
\text { 2. Meremas }\end{array}$ & $\begin{array}{l}\text { Menggaruk } \\
\text { kepala. } \\
\text { Memegang benda } \\
\text { kecil atau tipis } \\
\text { (misal: potongan } \\
\text { buah atau biskuit) } \\
\text { 3. Memukul- } \\
\text { mukul atau } \\
\text { mengetukngetuk } \\
\text { mainan. }\end{array}$ \\
\hline
\end{tabular}

Sumber: Permendiknas No. 58 Tahun 2009 tanggal 17 September 2009 Tentang Standar Pendidikan Anak Usia Dini. Hlm.3. 
Tabel 1.2 Perkembangan motorik kasar dan motorik halus usia 12 Bulan $-<4$ tahun

\begin{tabular}{|c|c|c|c|c|c|}
\hline \multirow[t]{2}{*}{ No } & \multirow{2}{*}{$\begin{array}{c}\text { Lingkup } \\
\text { Perkembangan }\end{array}$} & \multicolumn{4}{|c|}{ Tingkat Pencapaian Perkembangan } \\
\hline & & $\begin{array}{c}12-<18 \\
\text { bulan }\end{array}$ & $\begin{array}{c}18-<24 \\
\text { bulan }\end{array}$ & $\begin{array}{c}2-<3 \\
\text { tahun }\end{array}$ & $3-<4$ tahun \\
\hline 1. & Motorik Kasar & $\begin{array}{lr}\text { 1. } & \text { Berjalan } \\
\text { sendiri. } & 2 . \\
\text { Naik } & \text { tangga } \\
\text { atau } & \text { tempat } \\
\text { yang } & \text { lebih } \\
\text { tinggi dengan } & \text { merangkak. } 3 . \\
\text { Menendang } \\
\text { bola ke arah } \\
\text { depan. } 4 . \\
\text { Berdiri } & \text { dengan } \\
\text { satu } & \text { kaki } \\
\text { selama } & \text { satu } \\
\text { detik. }\end{array}$ & $\begin{array}{l}\text { 1. Melompat di } \\
\text { tempat. 2. Naik } \\
\text { tangga atau } \\
\text { tempat yang } \\
\text { lebih tinggi } \\
\text { dengan } \\
\text { berpegangan. } 3 . \\
\text { Berjalan } \\
\text { mundur } \\
\text { beberapa } \\
\text { langkah. } 4 . \\
\text { Menarik benda } \\
\text { yang tidak } \\
\text { terlalu berat } \\
\text { (kursi kecil). }\end{array}$ & $\begin{array}{l}\text { 1.Berjalan } \\
\text { sambil } \\
\text { berjinjit. } 2 . \\
\text { Melompat ke } \\
\text { depan dan ke } \\
\text { belakang } \\
\text { dengan dua } \\
\text { kaki. } 3 . \\
\text { Melempar } \\
\text { dan } \\
\text { menangkap } \\
\text { bola. } \\
\text { Menari } \\
\text { mengikuti } \\
\text { irama. } \\
\text { Naik-turun } \\
\text { tangga atau } \\
\text { tempat yang } \\
\text { lebih } \\
\text { tinggi/rendah } \\
\text { dengan } \\
\text { berpegangan. }\end{array}$ & $\begin{array}{l}\text { 1.Berlari sambil } \\
\text { membawa } \\
\text { sesuatu yang } \\
\text { ringan (bola). } 2 . \\
\text { Naik-turun } \\
\text { tangga atau } \\
\text { tempat yang } \\
\text { lebih tinggi } \\
\text { dengan kaki } \\
\text { bergantian. } 3 . \\
\text { Meniti di atas } \\
\text { papan yang } \\
\text { cukup lebar. } 4 . \\
\text { Melompat turun } \\
\text { dari ketinggian } \\
\text { kurang lebih 20 } \\
\text { cm (di bawah } \\
\text { tinggi lutut } \\
\text { anak). 5. Meniru } \\
\text { gerakan senam } \\
\text { sederhana } \\
\text { seperti } \\
\text { menirukan } \\
\text { gerakan pohon, } \\
\text { kelinci } \\
\text { melompat) }\end{array}$ \\
\hline 2 & Motorik Halus & $\begin{array}{l}\text { 1. Memegang } \\
\text { alat tulis. } 2 . \\
\text { Membuat } \\
\text { coretan bebas. } \\
\text { 3. Menyusun } \\
\text { menara dengan } \\
\text { tiga balok. } 4 . \\
\text { Memegang } \\
\text { gelas dengan } \\
\text { dua tangan. } 5 . \\
\text { Menumpahkan } \\
\text { bendabenda } \\
\text { dari wadah dan } \\
\text { memasukkann } \\
\text { ya kembali }\end{array}$ & $\begin{array}{l}\text { 1. Meniru garis } \\
\text { vertikal atau } \\
\text { horisontal. } 2 . \\
\text { Memasukkan } \\
\text { benda ke dalam } \\
\text { wadah yang } \\
\text { sesuai. } \\
\text { Membalik } \\
\text { halaman buku } \\
\text { walaupun } \\
\text { belum } \\
\text { sempurna. } \\
\text { Menyobek } \\
\text { kertas. }\end{array}$ & $\begin{array}{l}\text { 1. Meremas } \\
\text { kertas atau } \\
\text { kain dengan } \\
\text { menggerakka } \\
\text { n lima jari. } 2 . \\
\text { Melipat kertas } \\
\text { meskipun } \\
\text { belum } \\
\text { rapi/lurus. 3. } \\
\text { Menggunting } \\
\text { kertas tanpa } \\
\text { pola. } 4 . \\
\text { Koordinasi } \\
\text { jari tangan } \\
\text { cukup baik } \\
\text { untuk } \\
\text { memegang } \\
\text { benda pipih } \\
\text { seperti sikat } \\
\text { gigi, sendok }\end{array}$ & $\begin{array}{l}\text { 1. Menuang air, } \\
\text { pasir, atau biji- } \\
\text { bijian ke dalam } \\
\text { tempat } \\
\text { penampung } \\
\text { (mangkuk, } \\
\text { ember). } \\
\text { Memasukkan } \\
\text { benda kecil ke } \\
\text { dalam botol } \\
\text { (potongan lidi, } \\
\text { kerikil, biji- } \\
\text { bijian). } 3 . \\
\text { Meronce manik- } \\
\text { manik yang } \\
\text { tidak terlalu } \\
\text { kecil dengan } \\
\text { benang yang } \\
\text { agak kaku. } 4 . \\
\text { Menggunting } \\
\text { kertas mengikuti } \\
\text { pola garis lurus }\end{array}$ \\
\hline
\end{tabular}

Sumber: Permendiknas No. 58 Tahun 2009 tanggal 17 September 2009 Tentang Standar Pendidikan Anak Usia Dini. Hlm. 5-7. 
Tabel 1.3 Perkembangan motorik kasar dan motorik halus usia 4 tahun $-\leq 6$ tahun

\begin{tabular}{|c|c|c|c|}
\hline \multirow[t]{2}{*}{ No } & \multirow{2}{*}{$\begin{array}{c}\text { Lingkup } \\
\text { Perkembangan }\end{array}$} & \multicolumn{2}{|c|}{ Tingkat Pencapaian Perkembangan } \\
\hline & & Usia $4-<5$ tahun & Usia $5-\leq 6$ tahun \\
\hline 1. & Motorik Kasar & 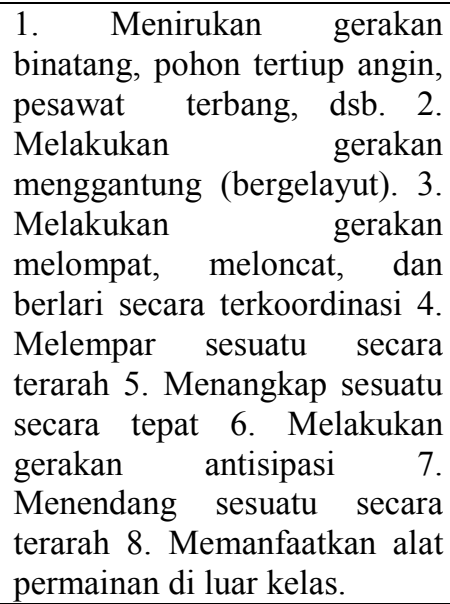 & $\begin{array}{l}\text { 1.Melakukan gerakan tubuh secara } \\
\text { terkoordinasi untuk melatih kelenturan, } \\
\text { keseimbangan, dan kelincahan. } \\
\text { Melakukan koordinasi gerakan kaki- } \\
\text { tangan-kepala dalam menirukan tarian atau } \\
\text { senam. 3. Melakukan permainan fisik } \\
\text { dengan aturan. 4. Terampil menggunakan } \\
\text { tangan kanan dan kiri. 5. Melakukan } \\
\text { kegiatan kebersihan diri. }\end{array}$ \\
\hline 2 & Motorik Halus & $\begin{array}{l}\text { 1. Membuat garis vertikal, } \\
\text { horizontal, lengkung } \\
\text { kiri/kanan, miring kiri/kanan, } \\
\text { dan lingkaran. 2. Menjiplak } \\
\text { bentuk. 3. Mengkoordinasikan } \\
\text { mata dan tangan untuk } \\
\text { melakukan gerakan yang } \\
\text { rumit. 4. Melakukan gerakan } \\
\text { manipulatif } \\
\text { menghasilkan suatu bentuk } \\
\text { dengan } \\
\text { berbagai media. } \\
\text { Mengekspresikan diri dengan } \\
\text { berkarya seni menggunakan } \\
\text { berbagai media }\end{array}$ & $\begin{array}{l}\text { 1.Menggambar sesuai gagasannya. } 2 . \\
\text { Meniru bentuk. 3. Melakukan eksplorasi } \\
\text { dengan berbagai media dan kegiatan. } 4 . \\
\text { Menggunakan alat tulis dengan benar. } 5 . \\
\text { Menggunting sesuai dengan pola. } 6 . \\
\text { Menempel gambar dengan tepat. } 7 . \\
\text { Mengekspresikan diri melalui gerakan } \\
\text { menggambar secara detail. }\end{array}$ \\
\hline
\end{tabular}

Sumber: Permendiknas No. 58 Tahun 2009 tanggal 17 September 2009 Tentang Standar Pendidikan Anak Usia Dini. Hlm. 8-9

Tabel 1.4 Perkembangan motorik kasar dan motorik halus usia 6 tahun $-\leq 8$ tahun

\begin{tabular}{|c|c|c|}
\hline \multirow[t]{2}{*}{ No } & \multirow{2}{*}{$\begin{array}{c}\text { Lingkup } \\
\text { Perkembangan }\end{array}$} & Tingkat Pencapaian Perkembangan \\
\hline & & Usia $6-<8$ Tahun \\
\hline 1. & Motorik Kasar & $\begin{array}{l}\text { 1.Berdiri dengan satu kaki tanpa jatuh, } 2 \text {. Berlari lurus tanpa jatuh dan } \\
\text { zigzag/bervariasi, misalnya melalui rintangan, 3. Berjalan lurus dan } \\
\text { bervariasi, } 4 \text {. Melompat dari ketinggian } 20 \mathrm{~cm}, 5 \text {. Melempar dan menangkap } \\
\text { bola kecil dengan jarak 5-10 meter, } 6 \text {. Mengkombinasikan gerakan jalan dan } \\
\text { lari, 7. Mengkombinasikan gerakan jalan, lari, melompat dan melempar, } 8 \text {. } \\
\text { Berguling kedepan/koprol. 9. Sudah dapat mengendarai sepeda roda dua. } 10 \text {. } \\
\text { Dapat menari dan mengikuti gerakan dalam senam irama. }\end{array}$ \\
\hline 2 & Motorik Halus & $\begin{array}{l}\text { 1.Menggambar orang dengan anggota tubuh lengkap, 2. Mampu makan, } \\
\text { minum dan berpakaian sendiri, 3. Membuat atau menulis angka, } 4 \text {. Membuat } \\
\text { bentuk wajik, segitiga dan segi empat, 5. Memotong dan menggunting } \\
\text { dengan sempurna, 6. Menggambar sesuai dengan penglihatan, } 7 \text {. Meniru } \\
\text { kalimat dengan tulisan tangan. }\end{array}$ \\
\hline
\end{tabular}

Sumber: Yuliani Nurani Sujiono, Konsep Dasar Pendidikan Anak Usia Dini, Jakarta: PT. Indeks, 2009. Hlm. 161-162.

Menurut Desmita (2013: 127-128) mengemukakan mengenai perkembangan fisik bahwa selama masa anak-anak awal, pertumbuhan fisik berlangsung lambat dibandingkan dengan tingkat pertumbuhan selama masa bayi. Pertumbuhan fisik yang lambat ini berlangsung sampai mulai munculnya tanda-tanda pubertas, yakni 
kira-kira 2 tahun menjelang anak matang secara seksual dan pertumbuhan fisik kembali berkembang pesat. Meskipun selama masa anak-anak pertumbuhan fisik mengalami perlambatan, namun ketrampilan-ketrampilan motorik kasar dan motorik halus justru berkembang pesat. Selain itu, tinggi dan berat anak selama masa anak-anak awal, tinggi ratarata anak bertumbuh 2,5 inci dan berat bertambah antara 2,5 hingga 3,5 kg setiap tahunnya. Pada usia 3 tahun, tinggi anak sekitar 38 inci dan beratnya sekitar 16,5 kg. Pada usia 5 tahun, tinggi anak mencapai 43,6 inci dan beratnya $21,5 \mathrm{~kg}$. Ketika anak usia pra sekolah bertumbuh makin besar, presentase pertumbuhan dalam tinggi dan berat berkurang setiap tahun. Selama masa ini, baik laki-laki maupun perempuan terlihat makin langsing, sementara batang tubuh mereka makin panjang.

Diantara perkembangan fisik yang sangat penting selama masa anak-anak awal ialah perkembangan otak dan sistem saraf yang berkelanjutan. Meskipun otak terus bertumbuh pada masa awal anakanak, namun pertumbuhannya tidak sepesat pada masa bayi. Pada saat bayi mencapai usia 2 tahun, ukuran otaknya rata-rata $75 \%$ dari otak orang dewasa, dan pada usia 5 tahun, ukuran otaknya telah mencapai sekitar $90 \%$ otak orang dewasa. Pertumbuhan otak selama awal masa anakanak disebabkan oleh pertambahan jumlah dan ukuran urat syaraf yang berujung di dalam dan diantara daerah-daerah otak. Ujung-ujung urat saraf itu terus bertumbuh setidak-tidaknya hingga masa remaja. Beberapa pertambahan ukuran otak juga disebabkan oleh pertambahan myelination, yaitu suatu proses dimana sel-sel urat saraf ditutup dan disekat dengan suatu lapisan sel-sel lemak. Proses ini berdampak terhadap peningkatan kecepatan informasi yang berjalan melalui sistem urat saraf. Beberapa ahli psikologi perkembangan percaya bahwa myelination adalah penting dalam pematangan sejumlah kemampuan anak-anak.
Perkembangan fisik pada masa anak-anak ditandai dengan berkembangnya keterampilan motorik, baik kasar maupun halus. Sekitar usia 3 tahun, anak sudah dapat berjalan dengan baik, dan sekitar usia 4 tahun anak hampir menguasai cara berjalan orang dewasa. Dan pada saat usia 5 tahun anak sudah terampil menggunakan kakinya untuk berjalan dengan berbagai cara, seperti maju dan mundur, jalan cepat dan pelanpelan, melompat dan berjingkrak, berlari ke sana ke mari, memanjat dan sebagainya yang semuanya dilakukan dengan lebih halus dan bervariasi. Selain itu, anak usia 5 tahun juga dapat melakukan tindakantindakan tertentu secar akurat, seperti menyeimbangkan badan di atas satu kaki, menangkap bola dengan baik, melukis, menggunting dan melipat kertas, dan sebagainya. (Desmita, 2013: 129)

\section{Definisi Permainan Tradisional}

Permainan adalah salah satu bentuk aktivitas sosial yang dominan pada awal masa anak-anak. Sebab, anak-anak menghabiskan lebih banyak waktunya di luar rumah bermain dengan temantemannya dibanding terlibat dalam aktivitas lain. (Desmita, 2013:141)

Setiap anak di dunia ini memiliki hak untuk bermain. Bermain juga adalah kegiatan pokok anak. Dengan bermain anak mendapatkan pengetahuan dan pengalaman yang membantu perkembangannya untuk menyiapkan diri dalam kehidupan selanjutnya. Para ahli pendidikan menganggap bahwa bermain sebagai kegiatan yang memiliki nilai praktis, artinya bermain digunakan sebagai media untuk meningkatkan keterampilan dan kemampuan tertentu pada anak. Bermain merupakan jembatan bagi anak dari belajar informal menjadi formal.

Dengan bermain, anak dapat melakukan kegiatan sehingga semua aspek perkembangan dapat berkembang secara maksimal. Bermain bukan hanya menjadi kesenangan saja, tetapi juga suatu kebutuhan yang mau tidak mau harus terpenuhi. Menurut Cony Semiawan, 
dalam kegiatan bermain, seluruh tahapan perkembangan anak dapat berfungsi dan berkembang dengan baik dan hasil dari perkembangan yang baik itu akan muncul dan terlihat pada saat si anak menginjak masa remaja. Bermain, atau permainan sebagai aktivitas terkait dengan keseluruhan diri anak, bukan hanya sebagian, namun melalui permainan (pada saat anak bermain) anak akan terdorong mempraktekkan keterampilannya yang mengarahkan perkembangan kognitif anak, perkembangan bahasa anak, perkembangan psikomotorik, dan perkembangan fisik. Pengalaman bermain akan mendorong anak untuk lebih kreatif. Mulai dari perkembangan emosi, kemudian mengarah ke kreativitas bersosialisasi. Ada beberapa prinsip permainan berdasarkan perilaku anak, yaitu antara lain: permainan adalah sesuatu yang menyenangkan, di luar dari peristiwa seharihari. Permainan adalah sarana bereksperimen dalam berbagai hal, terbuka tanpa batas. Permainan adalah sesuatu yang aktif dan dinamis, tidak statis sehingga tidak terbatas ruang dan waktu. Permainan juga berlaku bagi setiap anak di sepanjang zaman, memiliki konteks hubungan sosial dan spontan, bermain juga sebagai sarana komunikasi dengan teman sebaya dan lingkungan. (Ismatul Khasanah, 2011: 94)

Menurut Sukirman dalam Edy Waspada (2014: 16) bahwa definisi permainan tradisional adalah permainan anak-anak dari bahan sederhana sesuai aspek budaya dalam kehidupan masyarakat. Selain itu, permainan tradisional juga dikenal dengan permainan rakyat merupakan sebuah kegiatan rekreatif yang tidak hanya bertujuan untuk menghibur diri, tetapi juga sebagai alat untuk memelihara hubungan dan kenyamanan sosial.

\section{Jenis-jenis Permainan tradisional bagi Anak Usia Dini}

Motorik kasar adalah kemampuan gerak tubuh dalam menggunakan otot-otot besar, sebagian atau seluruh anggota tubuh motorik kasar diperlukan agar seseorang dapat duduk, memegang, berlari, menendang, memanjat pohon, menaiki tangga, dan sebagainya. Pada proses pertumbuhan seorang bayi perkembangan motorik kasarlah yang terlebih dahulu dipelajarinya, misalnya seorang bayi akan terlebih dahulu belajar memegang bendabenda yang berukuran besar di sekitarnya daripada yang berukuran kecil, ini dikarenakan bayi belum memiliki kemampuan untuk mengontrol jari-jemari tangannya.

Adapun sala hsatu jenis permainan yang lebih melatih kekuatan otot-otot anak yaitu permainan tradisional. Dalam situs http://srijasmaindra.blogspot.co.id/ yang telah penulis download pada tanggal 26 Oktober 2016 mengemukakan bahwa Jenis permainan tradisional untuk meningkatkan kemampuan motorik pada anak usia dini, diantaranya yaitu: 1)Permainan Congklak/dakon; 2) Lompat Tali/Sapintrong; 3) Kelereng.

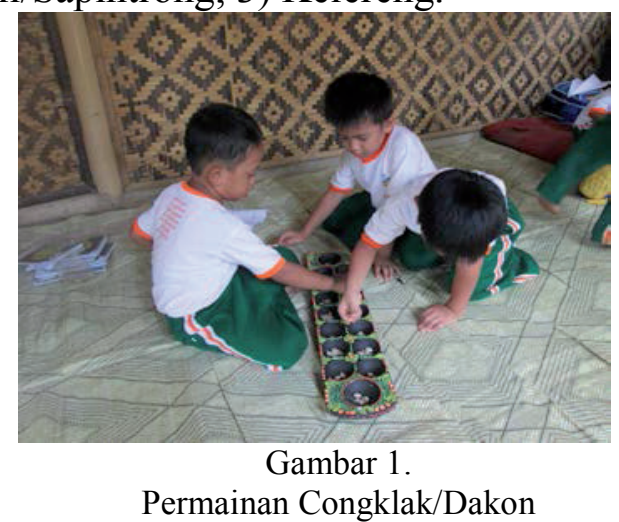

Bermain Congklak juga dapat melatih anak-anak pandai dalam berhitung. Selain itu, anak yang bermain congklak harus pandai membuat strategi agar bisa memenangkan permainan. Permainan yang disebut dakon dalam bahasa jawa ini, biasanya di mainkan oleh dua anak perempuan. Permainan congklak menggunakan papan uang yang disebut papan congklak. Ukuran papan terdiri atas 16 lubang untuk menyimpan biji congklak. Keenambelas lubang tersebut saling berhadapan dan 2 lubang besar dikedua sisinya. Kemudian anak-anak pun 
membutuhkan 98 biji congklak. Biji congklak yang biasanya di gunakan adalah cangkang kerang, biji-bijian, batu-batuan, kelereng atau plastik.

Dua lubang besar tersebut merupakan milik masing-masing pemain untuk menyimpan milik masing-masing pemain untuk menyimpan biji congklak yang di kumpulkannya. Dua lubang tersebut biasanya kosong sedangkan 14 lubang yang lain diisi 7 biji congklak. Adapun cara dalam melakukan permainan congklak, yaitu sebagai berikut:

1) Saat akan memulai permainan, setiap lubang di isi dengan 7 biji yang biasanya terbuat dari kerang atau plastik tetapi bairkan lubang induk tetap di kosongkan.

2) Tentukan siapa yang akan memulai permainan terlebih dahulu maka pemain dimulai dengan memilih salah satu lubang.

3) Kemudian sebarkan biji yang ada di lubang tersebut ketiap lubang lainnya searah dengan jarum jam. Masingmasing lubang di isi dengan 1 biji, jika biji yang terakhir jatuh di lubang yang ada bijiannya maka biji yang ada di lubang tersebut di ambil lagi, kemudian teruskan permainan dengan mengisi kembali lubang selanjutnya dengan biji yang diambil tadi. Jangan lupa untuk mengisiskan biji kelubang induk kita setiap melewatinya sedangkan lubang induk kawan tidak perlu di isi.

4) Bila biji terakhir ternyata masuk kedalam lubang induk kita, berarti kita bisa memilih lubang lainnya untuk memulai lagi,tetapi jika saat biji terakhir pada salah satu lubang yang kosong berarti giliran untuk lawan kita sementara permainan kita usai dan menunggu giliran selanjutnya.

5) Lubang tempat biji terakhir itu ada di salah satu dari 7 lubang yang ada dibaris kita, maka biji yang ada di seberang lubang tersebut beserta satu biji terakhir yang ada di lubang kosongakan mejadi milik kita dan akan di masukkan ke dalam lubang induk kita.

6) Setelah semua baris kosong maka permaina di mulai lagi dengan mengisis 7 lubang milik kita masingmasing 7 biji dari biji yang ada di lubang induk kita. Di mulai dari lubang yang terdekat dengan lubang induk. Bila tidak mencukupi maka lubang yang lainnya dibiarkan kosong dan selama permainan tidak boleh di isi dan kalau ada yang secara tidak sengaja mengisi lubang tersebut biji boleh di ambil siapa yang cepat mendapatkan biji tersebut akan menjadi miliknya secara otomatis

Dari permainan congklak di atas dapat mengembangkan berbagai aspek yang akan di kembangkan pada anak di antaranya yaitu sebagai berikut:

a) Melatih kemampuan motorik halus. Saat memegang dan memainkan biji congklak yang paling berperanan adalah motorik halus anak yaitu jari jemari. Bagi individu yang kemampuan kotorik halusnya tidak terlalu baik, maka ia tidak dapat menjalankan permainan tersebut dengan cepat dan mungkin saja bijibiji congklak tersebut akan tersebar dan terlepas dari genggamannya. Kemampuan motorik halus ini sangat bermanfaat bagi anak untuk memegang dan menggenggam alat tulis. Dengan kemampuan motorik halus yang baik maka anak dapat menulis bahkan mengetik dengan baik dan cepat.

b) Melatih kesabaran dan dan ketelitian (emosional). Permainan ini sangat memerlukan kesabran dan ketelitian. Terutama saat pemian harus membagikan biji congklak ke dalam lubang-lubang yang ada di depannya. Jika si pemain tidak sabar dan tidak teliti maka pemain tidak akan berjalan dengan baik dan pemian yang tidak bermain harus sabar menunggu giliran pemain yang sedang bermain terjatuh. 
c) Melatih jiwa sportifitas. Dalam permainan ini di perlukan kemampuan untuk menerima kekalahan karena permainan ini di lakukan hanya 2 orang saja maka akan terlihat jelas menang atau kalahnya. Kekalahan akan sangat terasa manakala si pemenang akan meninggalkan satu butir biji congklak saja.

d) Melatih kemampuan menganalisa (kognitif). Untuk bisa menjadi pemenang maka kemampuan untuk menganalisa sangat diperlukan terutama saat lawan mendapatkan giliran untuk bermain. Bagi yang mampu menganalisa dengan baik, ia dapat memenagkan permainan tersebut dengan hanya meninggalkan satu biji congklak saja

e) Menjalin kontak sosialisasi. Faktor ini merupakan hal terpenting dalam permainan ini karena di lakukan secara bersama-sama maka akan terjalinsuatu kontak sosial antara pemainnya. Berbagai macam informasi dapat di sampaikan saat permainan ini di lakukan tak jarang senda gurau dan tawa terdengar saat permainan ini berlangsung.

\section{Lompat Tali/Sapintrong}

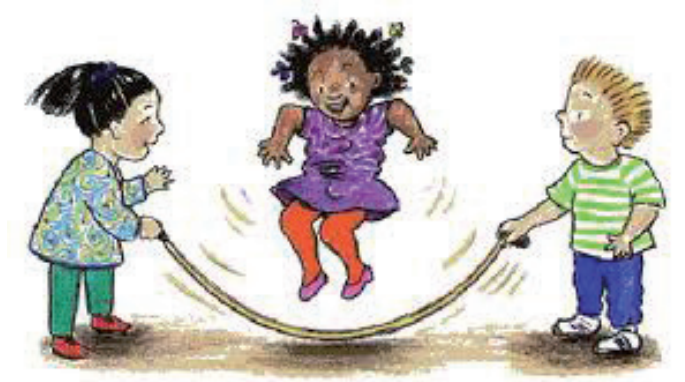

Lompat tali atau main karet pernah populer di kalangan anak-anak tahun 70-an hingga 80-an. Permainan lompat tali ini menjadi permainan favorite saat main di sekolah atau dirumah. Biasanya tali yang digunakan untuk permainan lompat tali ini di buat dari ronceaan tali dari karet gelang. Ini mengasah kekereatifan seorang anak dalam menjalin karet yang akan dipergunakan pada permainan tersebut.

Adapun cara untuk melakukan permainan lompat tali yaitu sebagai berikut:

1) Sesuaikan karet tali dengan tinggi badan pemain. Caranya berdiri sambil menginjak bagian tengah tali dan tarik ujung-ujung disamping badan. Panjang tali sudah pas jika ujung tali yang di pegang sampai di ketiak.

2) Karet tali di pegang erat dengan posisi lengan atas rapat dengan tubuh dan siku sejajar dipinggang. Kemudian berdiri dengan posisi agak jinjit dan lutut sedikit di tekuk. Usahakan kepala tetap tegak tapi tetap rileks serta pandangan lurus ke depan.

3) Pergelangan tangan digerakkan untuk memutar tali

4) Lompatan tidak terlalu tinggi saat tali menyentuh lantai, tinggi lompatan miximal $2,5 \mathrm{~cm}$ dari lantai. Pertahankan posisi agak jinjit saat mendarat dan tumit jangan menyentuh lantai.

5) Saat melompat harus hati-hati karena bisa jadi lompatan gagal.

6) Sebaiknya jika baru memulai permainan ini lakukan secara bertahap baru jika baru pandai biasa melakukan kombinasi gerakan.

Adapun aspek yang dapat dikembangkan dalam permainan ini yaitu sebagai berikut:

a. Motorik kasar. Dengan bermain lompat tali motorik kasar akan terstimulasi. Secara fisik hal itu akan membuat anak menjadi lebih terampil karena mempelajari cara dan teknik melompat yang dalam permainan ini memerlukan keterampilan tersendiri. Lama-kelamaan tumbuh menjadi anak yang cekatan, tangkas dan dinamis. Otot-ototnya pun padat dan berisi, kuat, tangkas serta terlatih. Lompat tali bisa mengurangi obesitas pada anak. 
b. Emosi. Lompat tali juga bisa melatih emosi anak. Untuk melakuka suatu lompatan dengan tinggi tertentu dibutuhkan keberanian dari diri anak. Berarti secara emosi ia di tuntut untuk membuat suatu keputusan besar.

c. Ketelitian dan akurasi. Seorang anak dengan lompat tali ini juga bisa belajar melihat suatu ketepatan dan ketelitian. Ketika tali di ayunkan ia harus dapat melompat sedemikian lupa sehingga tak dapat terjerat tali dengan berusaha mengikuti ritme ayunan.

d. Sosialisasi. Untuk bermain tali secara berkelompok anak membutuhkan teman dengan berarti memberi kesempatan untuk bersosialisasi. Ia juga dapat belajar berempat, bergiliran, menaati peraturan dan lainlain.

e. Intelektual. Saat melakukan lompatan terkadang anak perlu berhitung secara matematis agar lompatannya sesuai dengan jumlah yang telah di tentukan dalam aturan permainan.

Dibawah ini ada beberapa hal yang harus diperhatikan saat memainkan permainan ini yaitu:

a. Ruangan, permainan lompat tali di lakukan ditempat terbuka seperti lapangan atau halaman rumah. Permainan masih bisa di lakukan ditempat tertutup asalkan ruangan harus cukup lega dan lapang serta aman dari benda yang dapat membahayakan.

b. Ukuran tali, tali yang di pergunaka harus sesuai dengan ukuran tidak terlalu panjang atau tidak terlalu pendek.

c. Variasi permainan, semakin banyak variasi maka anak akan semakin mahir dan terampil dalam melakukan gerakan-gerakan.

d. Waktu sebaiknya di mainkan pada'waktu senggangatau jam istirahat sekolah karena anak akan biasanya keasyikan main sehingga lupa melakuka kativitas sebenarnya

\section{Permainan Kelereng}

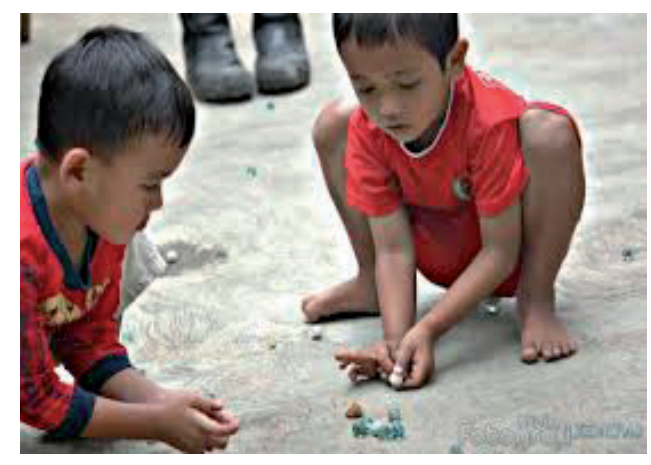

Permainan kelereng termasuk salah satu permainan rakyat yang sangat populer. Kelereng terbuat dari adonan semen dan kapur bentuknya yang bulat sebesar ibujari kaki atau terbuat dari batu wali yang dibentuk sedemikian rupa sehinnga menyerupai kelereng yang sebenarnya. Permainan ini sangat membutuhkan keahlian.

Adapun cara untuk melakukan permainan kelereng ini adalah sebagai berikut:

1. Cobalah jari tengah dan telunjuk ditekan dengan ibu jari sehingga membentuk angka nol.

2. Letakkan kelereng di antara pertemuan jari telunjuk dan ibu jari.

3. Lalu tekan dan dorong kelereng itu kuat-kuat dengan bantuan ibu jari kemudian lepaskan.

Peraturan dalam memainkan permain ini yaitu pada intinya tergantung dari pemain bagaimana jotosan atau lemparan kelereng lewat jari supaya mengenai kelereng lain. Nama permainan kelereng di antaranya disebut pot-potan, ban-banan atau jaru jam.

\section{a. Pengaruh Permainan Tradisional terhadap perkembangan motorik Anak Usia Dini}

Menurut Catron dan Allen dalam Yuliani Nurani Sujiono (2009: 145) mengemukakan bahwa pada dasarnya bermain memiliki tujuan utama yakni memelihara perkembangan dan pertumbuhan optimal pada anak usia dini melalui pendekatan bermain yang kreatif, 
interaktif dan terintegrasi dengan lingkungan bermain anak. Penekanan dalam bermain adalah kreativitas dari anak-anak. Semua anak usia dini memiliki potensi kreatif tetapi perkembangan kreativitas sangat individual dan bervariasi antar anak yang satu dengan anak lainnya. Selain itu, salah seorang murid dari Vygotsky menggambarkan empat prinsip bermain, yaitu: (1) dalam bermain anak mengembangkan sistem untuk memahami apa yang sedang terjadi dalam rangka mencapai tujuan yang lebih kompleks; (2) kemampuan untuk menempatkan perspektif orang lain melalui aturan-aturan dan menegosiasikan aturan bermain; (3) anak menggunakan replika untuk menggantikan objek nyata, lalu mereka menggunakan objek baru yang berbeda. Kemampuan menggunakan simbol termasuk kedalam perkembangan berpikir abstrak dan imajinasi; (4) kehati-hatian dalam bermain mungkin terjadi, karena anak perlu mengikuti aturan permainan yang telah ditentukan bersama teman mainnya.

Permainan tradisional sangatlah populer sebelum teknologi masuk ke Indonesia. Dahulu, anak-anak bermain dengan menggunakan alat yang seadanya. Namun kini, mereka sudah bermain dengan permainan-permainan berbasis teknologi yang berasal dari luar negeri dan mulai meninggalkan mainan tradisional. Seiring dengan perubahan zaman, Permainan tradisional perlahan-lahan mulai terlupakan oleh anak-anak Indonesia. Bahkan, tidak sedikit dari mereka yang sama sekali belum mengenal permainan tradisional.

Permainan

tradisional sesungguhnya memiliki banyak manfaat bagi anak-anak. Selain tidak mengeluarkan banyak biaya dan bias juga untuk menyehatkan badan bisa juga permainan tradisional adalah sebagai olaraga karena semua permainan mengunakan gerak badan yang ekstra, permainan tradisional sebenarnya sangat baik untuk melatih fisik dan mental anak. Secara tidak langsung, anak akan dirangsang kreatifitas, ketangkasan, jiwa kepemimpinan, kecerdasan, dan keluasan wawasannya melalui permainan tradisional. Para psikolog menilai bahwa sesungguhnya mainan tradisional mampu membentuk motorik anak, baik kasar maupun halus. Salah satu permainan yang mampu membentuk motorik anak adalah dakon. Motorik halus lebih digunakan dalam permainan ini. Pada permainan ini pemain dituntut untuk memegang biji secara utuh sembari meletakkannya satu-satu di kotakkannya dengan satu tangan.

Menurut Skinner dalam Sofia Hartati (2005: 24) beranggapan bahwa perilaku manusia yang dapat diamati secara langsung adalah akibat konsekuensi dari perbuatan sebelumnya. Kalau konsekuensinya menyenangkan maka hal itu akan diulangi lagi. Hal, tersebut sejalan dengan permainan tradisional yang prosesnya sangat digemari anak-anak. Permainan tradisional dapat mempermudah dalam pembelajaran gerak pada anak usia dini, proses pembelajarannya dapat digunakan di dalam pemanasan, inti, ataupun penenangan. Selain itu permainan tradisional juga memenuhi prinsip-prinsip belajar pada anak usia dini, yaitu; berangkat dari yang dimiliki anak, harus menantang pemahaman anak, dilakukan sambil bemain, menggunakan alam sebagai sarana pembelajarannya, dilakukan melalui sensorinya, membekali keterampilan hidup, dan belajar sambil melakukan.

Anak-anak sekarang hidup di zaman yang serba canggih. Banyak faktor yang membuat anak tidak sempat lagi menikmati menariknya berbagai permainan tradisional. Meskipun aksesnya tradisonal, tetapi justru bermacam-macam manfaat ada dalam permainan tradisional ini. Bergesernya minat anak-anak sekarang terhadap memilih permainan yang lebih modern dan elektronik dipicu juga oleh keadaan ekonomi dan faktor lingkungan tempat tinggal. Bermain game online di 
tablet, aneka game di mal, dan game berbasis elektronik lebih dipilih oleh anak sekarang ketimbang bermain kelereng, lompat tali, atau congklak. Kalau di pedesaan mungkin kita masih bisa melihat anak bermain petak umpet, lompat tali, congklak atau permainan sejenisnya tetapi di perkotaan pemandangan seperti itu sulit untuk ditemui lagi.

Menurut Desmita (2013: 141) menjelaskan bahwa permainan mempunyai arti yang sangat penting bagi perkembangan kehidupan anak-anak.

Selain itu, dalam situs
https://keluarga.com/ yang telah
didownload oleh penulis pada tanggal 26 Oktober 2016 mengemukakan bahwa terdapat manfaat dan pengaruhnya permainan tradisional bagi perkembangan anak usia dini, diantaranya yaitu:

\section{Anak belajar sportifitas}

Melalui permainan tradisional seperti congklak, anak belajar nilai sportif, di mana anak belajar menerima kekalahannya atau kemenangan lawannya secara terbuka, bermain secara jujur dan menghargai lawannya. Orangtua bisa memberi apresiasi kepada anak terhadap pencapaian yang diperolehnya. Menang atau kalah bukan menjadi tujuan sebuah permainan tetapi hargailah anak kita karena ia bisa bersikap sportif.

2. Melatih kemampuan fisik anak

Permainan modern sekarang ini jarang yang menguras tenaga. Permainan sekarang dibuat lebih praktis dan simpel. Tidak sama dengan permaianan tradisional seperti perbentengan, lompat tali yang membutuhkan banyak gerakan. Permaianan ini sangat membantu motorik anak dalam melaraskannya dengan berkoordinasi dengan anggota tubuh lainnya. Aktivitas ini sangat membantu perkembangan kecerdasan kinestetik anak berhubungan dengan setiap gerakan gerakan anak.
3. Lebih bersosialisasi

Hampir semua permainan tradisional menekankan kebersamaan. Tanpa lawan atau teman, anak tidak bisa bermain suatu permainan. Itulah hebatnya permainan tradisional. Di sini anak belajar bagaimana berhubungan dengan orang lain, tidak secara individual, belajar menunggu giliran, belajar berbagi dan belajar jujur dalam bermain.

4. Menggali kreativitas

Beberapa permainan tradisonal seperti congklak dan membuat mobilmobilan dari kulit jeruk bali ternyata bisa mengasah kreativitas anak. Anak dilatih untuk menyusun strategi permainan agar bisa menang atau menciptakan permainan permainan baru dari bahan yang mudah ditemukan. Pada permainan tradisional, pemain dituntut lebih kreatif membuat peraturan permainan sendiri.

5. Belajar arti dari saling bekerja sama Hampir semua permaianan tradisional dilakukan secara berkelompok. Pentingnya saling kerja sama dan membantu tim dalam meraih kemenangan wajib dilakukan. Pada permainan ini anak diajar agar tidak egois dan memberi kesempatan pada timnya agar sama sama mempunyai kesempatan dalam bermain.

6. Meningkatkan kepercayaan diri anak Rasa percaya diri sangat dibutuhkan bagi setiap anak untuk masa depannya. Ketika memulai untuk bermain, tidak ada satu pun anak yang berharap akan kalah duluan, melalui permainan tradisional anak akan belajar mengeluarkan semua kemampuannya untuk menang dan mengalahkan lawannya. Rasa percaya diri inilah yang menjadi bekalnya kelak.

7. Belajar mengelola emosi

Pada saat bermain, anak akan meluapkan emosinya dengan berteriak, tertawa, dan bergerak. Keterampilan 
mengelola emosi secara tepat penting untuk dipelajari demi melatih kecerdasan emosional anak.

8. Mengajari anak untuk menghargai prestasi orang lain

Dalam beberapa permainan tradisional, anak dituntut untuk bisa menerima kekalahan tim jika timnya kalah. Menghargai kemenangan tim lawan membuat anak belajar untuk berbesar hati dan ikhlas.

9. Belajar bersikap demokratis

Pada permainan tradisional, anak-anaklah yang menentukan syarat dan ketentuan dalam bermain. Anak anak belajar berunding membuat keputusan siapa yang akan memulai permainan pertama. Anak juga berunding dalam membagi kelompok bermain.

\section{KESIMPULAN}

Anak-anak sangat menikmati permainan dan akan terus melakukannya dimanapun mereka memiliki kesempatan. Bermain adalah suatu kegiatan yang sering dilakukan oleh anak-anak dan dapat menimbulkan kesenangan/kepuasan bagi diri seseorang. Kegiatan bermain dapat membantu anak mengenal tentang diri sendiri, dengan siapa ia hidup serta lingkungan tempat dimana ia hidup.

$$
\text { Permainan tradisional }
$$

sesungguhnya memiliki banyak manfaat bagi anak-anak. Selain tidak mengeluarkan banyak biaya dan bias juga untuk menyehatkan badan bisa juga permainan tradisional adalah sebagai olaraga karena semua permainan mengunakan gerak badan yang ekstra, permainan tradisional sebenarnya sangat baik untuk melatih fisik dan mental anak. Secara tidak langsung, anak akan dirangsang kreatifitas, ketangkasan, jiwa kepemimpinan, kecerdasan, dan keluasan wawasannya melalui permainan tradisional. Para psikolog menilai bahwa sesungguhnya mainan tradisional mampu membentuk motorik anak, baik kasar maupun halus. Selain itu, terdapat keterkaitan 3 jenis permainan tradisional yaitu berupa: (1) Permainan Congklak/Dakon; (2) Lompat Tali/Sapintrong; (3) Permainan Kelereng dengan motorik anak bahwa kemampuan fisik motorik anak usia dini tidak akan berkembang tanpa adanya kematangan kontrol motorik, dan motorik tersebut tidak akan optimal jika tidak diimbangi dengan gerakan anggota tubuh tanpa dengan latihan fisik.

\section{DAFTAR PUSTAKA}

Abu Ahmadi \& Munawar Sholeh, Psikologi Perkembangan, (Jakarta: PT. Rineka Cipta, 2005).

Agoes Dariyo, Psikologi Perkembangan Anak Tiga Tahun Pertama, (Bandung: PT. Refika Aditama, 2007).

Ahmad Susanto, Perkembangan Anak Usia Dini, (Jakarta: PT. Kencana, 2011).

Desmita, Psikologi Perkembangan, (Bandung: PT. Remaja Rosdakarya, 2013).

Edy Waspada, "Perbedaan pengaruh permainan tradisional dan latihan kecerdasan kinestetik terhadap kemampuan motorik dan kecerdasan emosional", dalam TESIS, (Surakarta: Universitas Sebelas Maret), 2014.

Helmawati, Mengenal dan memahami PAUD, (Bandung: PT. Remaja Rosdakarya, 2015)

http://srijasmaindra.blogspot.co.id/2012/1 2/macam-macam-permainantradisional-pada.html.

https://keluarga.com/2961/pengasuhan/9manfaat-memperkenalkanpermainan-tradisional-kepadaanak 
Ihsana El-Khuluqo, Manajemen PAUD (Pendidikan Anak Usia Dini): Pendidikan Taman Kehidupan Anak, (Yogyakarta: PT. Pustaka Pelajar, 2015).

Latif, Mukhtar, dkk., Orientasi Baru Pendidikan Anak Usia Dini, (Jakarta: Kencana Prenada Media Group, 2013).

Moeslichatoen, Metode Pengajaran Di Taman Kanak-kanak, (Malang: Departemen Pendidikan Dan Kebudayaan, 2006).

Mursid, Belajar dan Pembelajaran PAUD, (Bandung: PT. Remaja Rosdakarya, 2015).

Novan Ardy Wiyani \& Barnawi, Format PAUD Konsep, Karakteristik \& Implementasi Pendidikan Anak Usia Dini, (Jogjakarta: Ar-Ruzz Media, 2012)

Permendiknas No. 58 Tahun 2009 tanggal 17 September 2009 Tentang Standar Pendidikan Anak Usia Dini.

Sofia Hartati, Perkembangan Belajar pada Anak Usia Dini, (Depdiknas Dirjen Dikti. Jakarta, 2005).

Syamsu Yusuf LN, Psikologi Perkembangan Anak\&Remaja, (Bandung: PT. Remaja Rosdakarya, 2014)

Yeni Rachmawati\& Euis Kurniati, Strategi Pengembangan Kreativitas pada Anak Usia Taman Kanak-kanak, (Jakarta: Kencana Prenada Media Group, 2011).

Yuliani Nurani Sujono, Konsep Dasar Pendidikan Anak Usia Dini, (Jakarta: PT. Indeks, 2009) 